\title{
New records of Paracrias Ashmead (Hymenoptera, Eulophidae) as parasitoids on weevil larvae (Coleoptera, Curculionidae) in Brazil, with the description of a new species
}

\author{
Luciano Palmieri ${ }^{1}$, Fernando H. A. Farache ${ }^{1}$, Rodrigo A. S. Pereira ${ }^{1} \&$ Christer Hansson ${ }^{2}$ \\ 1. Universidade de São Paulo, Pós-Graduação em Entomologia, Departamento de Biologia, FFCLRP, 14040-901 Ribeirão Preto, São Paulo, Brazil. (lucian0palmieri@yahoo.com.br, \\ fhafarache@gmail.com, raspereira@yahoo.com.br) \\ 2. Scientific Associate of the Natural History Museum, London SW7 5BD, United Kingdom. (christerdennis@gmail.com)
}

\begin{abstract}
Paracrias strii Schauff, 1985 and P. ceratophaga Palmieri \& Hansson sp. nov. are first record in Brazil and both are associated with Ceratopus Schoenherr larvae (Coleoptera, Curculionidae) reared from syconia of two species of fig-trees. Both Paracrias species are diagnosed and illustrated. Males of $P$. ceratophaga sp. nov. are described. The association of Paracrias with weevil larvae is briefly discussed.
\end{abstract}

KEYWORDS. Ceratopus, Entedoninae, Ficus, Neotropical region, taxonomy.

RESUMO. Novos registros de Paracrias Ashmead (Hymenoptera, Eulophidae) como parasitoides de larvas do gorgulho (Coleoptera, Curculionidae) no Brasil, com a descrição de uma nova espécie. Paracrias strii Schauff, 1985 e P. ceratophaga Palmieri \& Hansson sp. nov. são registradas pela primeira vez para o Brasil, sendo associadas a larvas de Ceratopus Schoenherr (Coleoptera, Curculionidae) obtidas de sicônios maduros de duas espécies de figueiras. As espécies registradas foram ilustradas. Os machos de P. ceratophaga sp. nov. foram descritos. A associação do gênero Paracrias com besouros curculionídeos é discutida brevemente.

PALAVRAS-CHAVE. Ceratopus, Entedoninae, Ficus, Região Neotropical, Taxonomia.

Paracrias Ashmead, 1904 comprises 64 species and is predominantly distributed in the Neotropical region (HANSSON, 2002). They are recognized by having a lenticular head with upper occiput concave so that posterior ocelli is very close to or touching occipital margin; pronotum without transverse carina; propodeum with median carina smooth or partially reticulate and with reticulate submedian grooves; scutellum without median groove; forewing usually with continuous submarginal and marginal veins (HANSSON, 2002).

The genus was first described by Schauff (1985) as belonging to Entedoninae (Eulophidae) and including six species. Later, six new species were included by Gumovsky (2001) in the first review of the genus. The number of Paracrias species was then considerably increased after the work of Hansson (2002), who included 52 new species in the genus.

The biology of Paracrias species is very poorly known with only three species having a biological record, and all are parasitoids on weevil larvae. Paracrias guatemalensis Schauff, 1985 is a parasitoid on Conotrachelus perseae Barber, 1919 (Schauff, 1985), P. anthonomi Woolley \& Schauff, 1987 on Anthonomus hunteri Burke \& Cate, 1979 (Woolley \& Schauff, 1987); and P. mirus Girault, 1917 on Lignyodes bischoffi (Blatchley, 1916) (SChaufF, 1985). Here we add host information for two additional Paracrias species, P. strii Schauff, 1985 and P. ceratophaga sp. nov., which is described here. Both species are also parasitoids on weevil larvae.

\section{MATERIAL AND METHODS}

The specimens studied emerged from Ceratopus Schoenherr, 1843 (Curculioninae) larvae living in fruits of Ficus spp. (hereafter referred to as figs). Figs were collected from $F$. obtusifolia Kunth and F. trigona L. f. growing at Estação Ecológica dos Caetetus, a fragment of atlantic semideciduous forest in southeastern Brazil $\left(22^{\circ} 24^{\prime} \mathrm{S}, 49^{\circ} 41^{\prime} \mathrm{W}\right)$. Between December 2010 and November 2011 the trees were checked monthly for ripe or near ripe figs. When available, approximately two hundred figs were collected and kept in glass vials of $\sim 3 \mathrm{~L}$ under laboratory conditions (approx. $25^{\circ} \mathrm{C}$ and 12 hours of light) for up to two weeks. All emerging insects were collected and stored in 70\% ethanol.

The specimens were subsequently critical point dried (GORDH \& HALL, 1979) using BALTEC CPD 030' and card-mounted following NOYES (1982). Morphological terminology follows GiBson (1997). Images were taken with auto-montage stereomicroscope. Leica Application Suite (LAS) V3.6 imaging software was used in order to merge image series comprising 15-20 focal planes and produce a single image with increased depth of field. The images were then edited using GIMP 2.8.0 (open software). The acronyms of museums, following ARNETT et al. (1993), are: BMNH, The Natural History Museum, London, England; MZSP, Museu de Zoologia, Universidade de São Paulo, São Paulo, Brazil; NMNH, National Museum of Natural History, Smithsonian Institution, Washington D.C., United States of America. 


\section{RESULTS}

Only adults of the same species of Ceratopus and Paracrias wasps emerged from the figs, which allowed us to associate the wasps with their host. Both males and females of $P$. strii emerged from vials containing weevils on $F$. obtusifolia. Additionally, only two males of $P$. ceratophaga sp. nov. emerged from the vials containing weevils on F. trigona.

\section{Paracrias ceratophaga Palmieri \& Hansson sp. nov.} (Figs 1-6)

Diagnosis. Similar to $P$. strii through indistinct scrobes and frontal suture, noted only by changes in sculpturing (Fig. 3); rounded occipital margin (Fig. 4); short malar space, less 1/5 mouth width; dorsellum split by propodeal median carina (Fig. 5); propodeal callus with two setae. Differs from P. strii in that the male flagellomeres are cylindrical and symmetric (Fig. 2), in P. strii male flagellomeres are flattened and asymmetric.

Description. Male, measurements $(\mathrm{mm})$ : total length 3.0 ; width of mouth 0.41 ; malar space 0.04 ; height of eye 0.55 ; head height 1.01 ; scape 0.43 ; pedicel 0.11 length, 0.06 width; $1^{\text {st }}$ funicule 0.13 length, 0.07 width; head width 0.33 ; postocellar distance 0.20 ; ocular-ocellar line 0.09 ; mesosoma 1.53 length, 0.84 width; propodeum length 0.47 ; gaster length 1.09 ; petiole 0.57 length, 0.25 width; hind tibia length 0.84 ; hind tibial spur length 0.17 ; hind tarsus length 0.66 ; forewing length 2.0.

Body predominantly black with metallic blue tinges (Figs. 1-5). Scape pale. Pedicel brown-black with metallic blue tinges. Flagellum yellow-brown (Fig. 2). Fore, mid and hind coxae with same color as mesosoma, other leg segments pale yellow; hind femur slightly brown in distal part. Metasoma brownblack (Fig. 1). Wings hyaline (Fig. 6). Antennal clava pointed, with three segments, without sensilla on ventral surface (Fig. 2). Head in lateral view 1.7x as high as long. Eyes bare. Frons reticulate and not protruding (Fig. 3). Frontal suture indistinct, V-shaped, indicated by changes in sculpturing only. Vertex partially reticulate (Fig. 3). Occipital margin rounded (Fig. 4). Prepectus reticulate medially. Scutellum strongly reticulate. Propodeal median carina reticulate (Fig. 5). Propodeal callus with two setae. Forewing costal cell bare. Postmarginal vein absent. Hind coxa with few scattered setae. Hind tibial spur $0.3 \mathrm{x}$ as long as hind tarsus. Petiole bare, without anteroventral carina. Petiole 1.6x as long as wide. Hind margin of $1^{\text {st }}$ gastral tergite curved backwards, bare in anterolateral part. Hind margin of $2^{\text {nd }}$ tergite incised.

Female. Unknown.

Distribution. State of São Paulo, Brazil.
Biology. Reared from ripe figs of Ficus trigona (Moraceae) containing Ceratopus sp. larvae.

Type material. Holotype $\widehat{\partial}$, BRAZIL, São Paulo: Gália (Estação Ecológica dos Caetetus, 22 K 635973 E 7524644 S, córrego Alegre, $659 \mathrm{~m}$ ), 02.XII.2010, L. Palmieri col. (MZSP). FCA016 (EEC), Ex. Ficus trigona fase D. Paratype $\hat{\delta}$, Idem $(\mathrm{BMNH})$.

Etymology. From the Greek keratos, horn, and phagein, to eat, i.e. ceratophaga, in reference to the host genus.

Remarks. The paratype lacks both antennae and the right pair of wings.

\section{Paracrias strii Schauff, 1985}

(Figs 7-12)

Paracrias strii SchaufF, 1985:105, figs 3-16 (holotype $q$ from Barro Colorado Island, Canal Zone, Panama, X.1937, from Ficus fruit, deposited in NMNH type no. 101168, examined)

Material examined. BRAZIL, São Paulo: Gália (Estação Ecológica dos Caetetus, 22 K 635909 E 7524387 S, córrego Alegre, 649 m.), 20, 7ㅇ, 09.IV.2011, L. Palmieri col. (MZSP, BMNH). EEC460 (EEC), Ex. Ficus obtusifolia fase D.

Diagnosis. Male flagellomeres flattened and asymmetric (Fig. 10); antennal scrobes and frontal suture indistinct, noted only by changes in sculpturing (Fig. 8); occipital margin rounded (Fig. 11); malar space short (Fig. 8), less 1/5 mouth width; dorsellum split by propodeal median carina; propodeal callus with two setae (Fig. 12).

Distribution. Panama and state of São Paulo, Brazil (new record).

Biology. Reared from ripe figs of Ficus obtusifolia (Moraceae) containing Ceratopus sp. larvae.

\section{DISCUSSION}

Prior to this research only three host records for Paracrias species were known, and all three were associated with weevil larvae. We found that two additional species of Paracrias wasps were also associated with weevils. It seems that this genus of parasitoid wasps is specialized on curculionid beetle larvae. Since Ceratopus beetles seem to breed specifically on fig trees in the Neotropics (PAKaluK \& CARLOW, 1994), and the two plant species studied here have a large distribution, $F$. obtusifoila from southern Mexico to southeast Brazil and F. trigona all over tropical South-America (BERG \& VilLaVicencio, 2004), we cannot reject the hypothesis that both Paracrias species have the same large distribution. This assumption is indicated by $P$. strii, which is found in Panama and southeast Brazil. However, it is a matter to be tested for P. ceratophaga. 

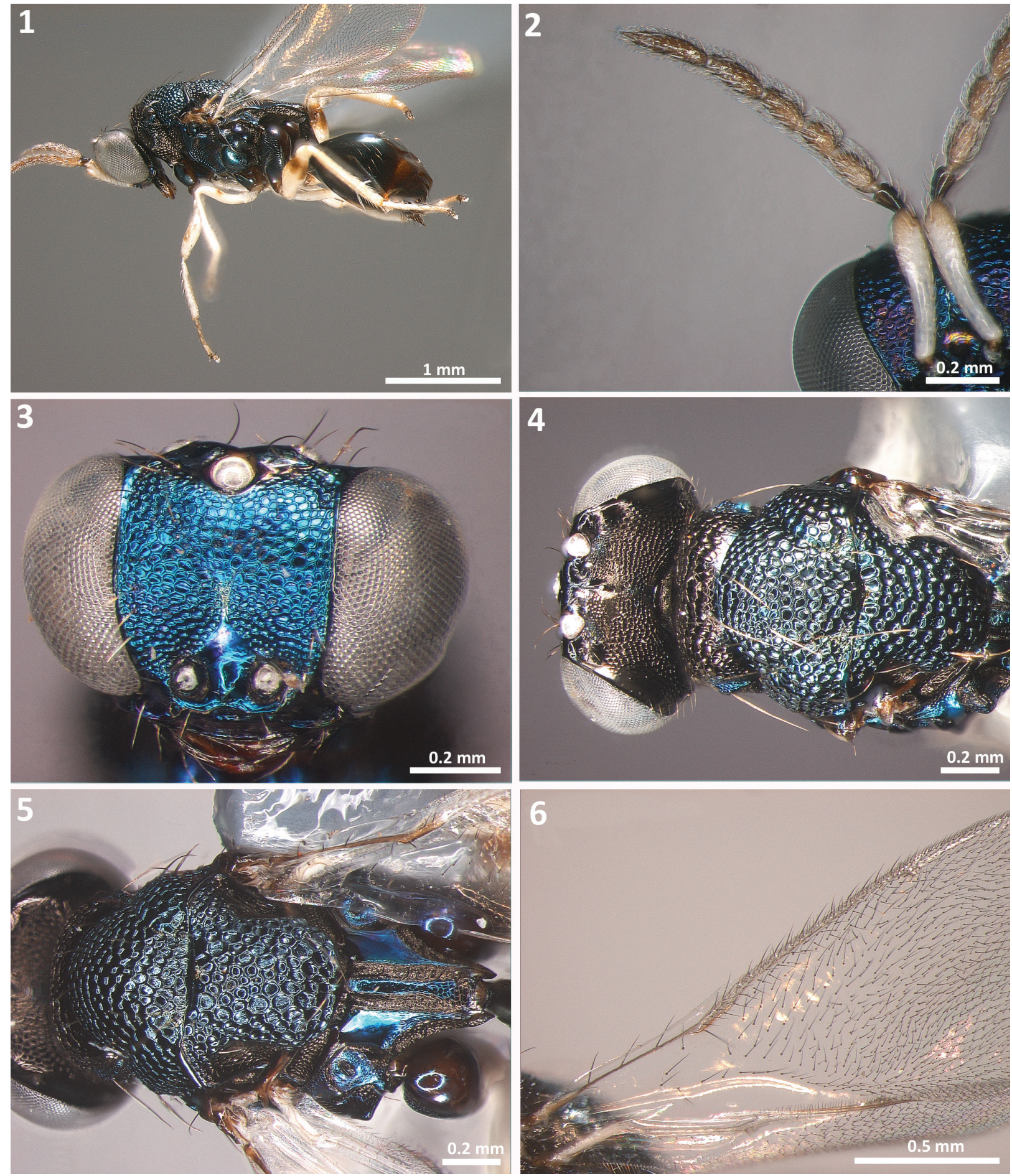

Figs 1-6. Paracrias ceratophaga Palmieri \& Hansson sp. nov., male: 1, lateral habitus; 2, antennae; 3, head, frontal; 4, head and anterior part of mesosoma in dorsal view; 5 , propodeum; 6 , forewing venation. 

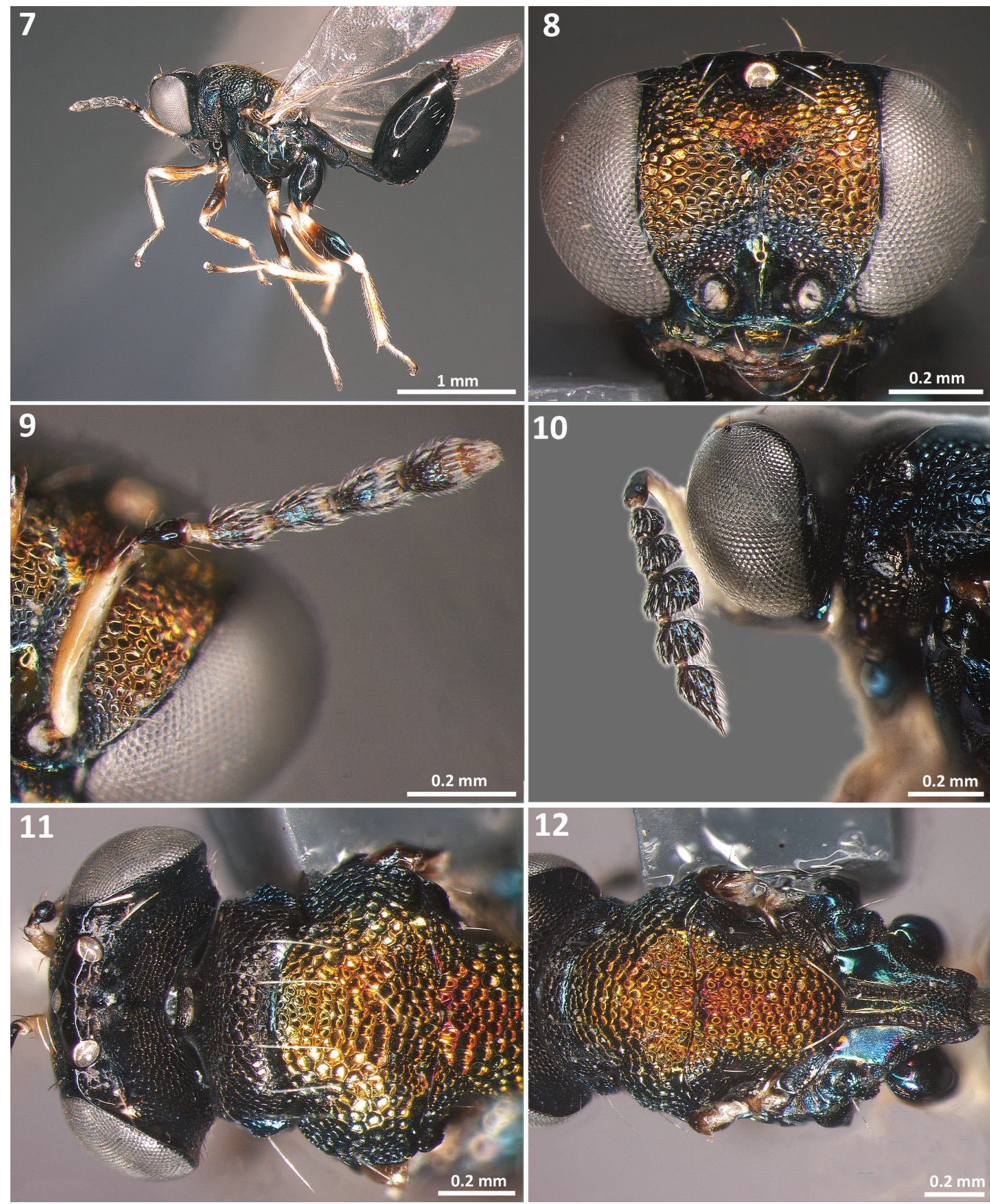

Figs 7-12. Paracrias strii Schauff, 1985: 7, lateral habitus, female; 8, frons, female; 9, antenna, female; 10, antenna, male; 11, head and anterior part of mesosoma, dorsal view; 12, mesosoma. 
Acknowledgements. L.P. and R.A.S.P. were funded by Conselho Nacional de Desenvolvimento Científico e Tecnológico (\#134866/201-0, \#303590/211-4). F.H.A.F. and R.A.S.P. were funded by Fundação de Amparo à Pesquisa do Estado de São Paulo (\#2010/51158-5, \#2004/10299-4).

\section{REFERENCES}

Arnett, R. H.; Samuelson, G. A. \& Nishida, G. M. 1993. The Insect and Spider Collections of the World. Gainesville, Sandhill Crane Press. 310p.

Berg, C. C. \& Villavicencio, X. 2004. Taxonomic studies on Ficus (Moraceae) in the West Indies, extra-Amazonian Brazil, and Bolivia. Ilicifolia 4:1-132.

GiBson, G. A. P. 1997. Morphology and terminology, p.16-44. In: Gibson, G. A. P.; Huber, J. T. \& Woolley, J. B. eds. Annotated Keys to the Genera of Nearctic Chalcidoidea (Hymenoptera). Ottawa, National Research Council Press. 794p.
GoRdH, G. \& HaLl, J. 1979. A critical point drier used as a method of mounting insects from alcohol. Entomology Newsletter 90:57-59.

Gumovsky, A. 2001. Review of the genus Paracrias (Hymenoptera, Eulophidae, Entedoninae). Vestnik Zoologii 35:9-26.

Hansson, C. 2002. Eulophidae of Costa Rica, 1. Memoirs of the American Entomological Institute 67:1-290.

NOYES, J. 1982. Collecting and preserving chalcid wasps (Hymenoptera: Chalcidoidea). Journal of Natural History 16:315-334.

PaKaluK, J. \& Carlow, T. A. 1994. Description of the larva of an unidentified species of Ceratopus Schoenherr, with comments on plant associations in Ceratopodinae (Coleoptera: Curculionidae) Journal of the New York Entomological Society 102:350-354.

Schauff, M. E. 1985. The New World genus Paracrias Ashmead (Hymenoptera: Eulophidae). Proceedings of the Entomological Society of Washington 87:98-109.

Woolley, J. B. \& Schauff, M. E. 1987. A new species of Paracrias (Hymenoptera, Eulophidae) parasitic on Anthonomus spp. (Coleoptera: Curculionidae). Proceedings of the Entomological Society of Washington 89:770-775. 